\title{
Synthesis of immobilized biocatalysts for wastewater decontamination
}

\author{
Thâmara Machado e Silva ${ }^{1}$, Leonardo Luiz Borges ${ }^{1}$, Eli Regina Barboza e Souza² \\ and Samantha Salomão Caramori* ${ }^{1 *}$ \\ 'Laboratório de Biotecnologia, Universidade Estadual de Goiás - UEG, Anápolis, G0, Brasil \\ ${ }^{2}$ Escola de Agronomia, Universidade Federal de Goiás - UFG, Goiânia, GO, Brasil \\ *sscaramori@gmail.com
}

\begin{abstract}
The use of biodegradable polymers arouses biotechnological interest. This use allows applications in health and environment. Here is present the characterization and a proposition for the use of cashew (Anacardium othonianum Rizz.) polysaccharide including peroxidase immobilization for wastewater bioremediation. From the cashew gum exudate, the polysaccharide was extracted by precipitation in ethanol at $4{ }^{\circ} \mathrm{C}$. This material is able to immobilize Horseradish peroxidase by physical adsorption and via sodium periodate with $75 \%$ and $93 \%$ of efficiency, respectively. These systems have a storage and operational stability, and removed phenolic compounds above $50 \%$ in industrial effluent samples. The bioassays in the presence of Artemia salina and Allium cepa root not only revealed no toxicity to this polysaccharide, but also presented the ability to reduce the toxicity of the industrial effluent by $50 \%$. Immobilized cashew polysaccharide complexes are potential alternatives for waste treatment and decontaminant agents for water treatment applications. The polysaccharide is a low-cost natural matrix for environmental-technological applications.
\end{abstract}

Keywords: bioremediation, ecological toxicity, natural polymers, peroxidase immobilization.

How to cite: Silva, T. M., Borges, L. L., Souza, E. R. B., \& Caramori, S. S. (2019). Synthesis of immobilized biocatalysts for wastewater decontamination. Polímeros: Ciência e Tecnologia, 29(4), e2019056. https://doi.org/10.1590/0104-1428.08918

\section{Introduction}

Natural polymers generate a significant interest in research and industrial communities because their renewable origins reduce the accumulation of waste and cause less environmental impacts. They easily degrade throughout the industrial processes ${ }^{[1]}$. Such materials have also been used as thickeners, gelling agents, emulsifiers, stabilizers, binders, and biodegradable products ${ }^{[2]}$, and for enzyme immobilization $^{[3]}$.

The Cerrado, the second largest Brazilian biome in area (approximately $22 \%$ of the country area), is home to the Cerrado arboreal cashew (Anacardium othonianum Rizz. $)^{[4]}$. The water solubility of the polysaccharide from A. othonianum (PEJU) makes it an attractive support for enzyme immobilization, since its recovery can easily be achieved by simple precipitation with polar organic solvents, such as ethanol ${ }^{[3]}$.

An alternative for the treatment of phenolic wastewater is the use of peroxidase (E.C.1.11.1.7). Such use was first proposed by Klibanov and collaborators ${ }^{[5]}$, and has been continually improved to optimize technical and economic factors. This enzyme successfully eliminates phenol from aqueous solutions, thus being the most researched peroxidase. For the treatment of large volumes of pesticides ${ }^{[6]}$, antibacteria ${ }^{[7]}$ and textile effluents ${ }^{[8]}$, reactors containing immobilized peroxidase are desirable because it enables enzyme recovery/recycling, thus decreasing costs of bioremediation $^{[7]}$.

The immobilization technique allows enzyme recovery and reusability, and admits a continuous conversion process $^{[9]}$. The microenvironment in which immobilization occurs protect the enzyme chemical structure, sometimes offering charged groups (if the support has an ionic matrix), sometimes establishing multiple covalent bonds in order to avoid denaturation ${ }^{[6,7]}$. Depending on the nature of the support and the chemical method adopted to obtain the immobilized-enzyme system, it is possible to enhance catalytic efficiency, even using recalcitrant molecules as substrates $^{[8]}$.

The literature on peroxidase immobilization involves functionalizing steps with toxic agents, such as glutaraldehyde ${ }^{[3,7,10]}$, or uses not suitable large-scale materials, such as bioaffinity chromatography ${ }^{[9]}$. This paper proposes the immobilization of horseradish peroxidase in Cerrado-arboreal cashew (Anacardium othonianum Rizz.) polysaccharide as an alternative to remove phenols and reduce biological toxicity (assays by Artemia salina and Allium серa) of wastewater. This bio-based treatment represents an eco-friendly strategy to treat wastewater using immobilized peroxidase. Two immobilization methods are presented: the first is based on direct enzyme adsorption for the support; the second is based on binding via sodium periodate. 
The hypothesis of this work is that the Cerrado-arboreal cashew polysaccharide is able to immobilize peroxidase and the polysaccharide-HRP complex can be applied to treat industrial effluents.

\section{Materials and Methods}

\subsection{Material}

Horseradish peroxidase Type IV (E.C. 1.11.1.7), ethanol P.A., pyrogallol, hydrogen peroxide $\left(\mathrm{H}_{2} \mathrm{O}_{2}\right) 35 \%(\mathrm{v} / \mathrm{v})$, sodium phosphate monobasic, potassium dichromate, sodium periodate, nitrophenol, phenol, bromophenol, catechol, Giemsa stain, sodium azide, and the Folin-Ciocalteu reagent were purchased from Sigma-Aldrich (USA).

The in natura gum $(\mathrm{G})$ and polysaccharide (PEJU) characterizations were carried out according to Silva et al. ${ }^{[11]}$. Briefly, the gum in natura $(\mathrm{G})$ was obtained through incisions in the trunks of 24 individuals of cashew trees implanted in an arboretum in Goiânia, Goiás state (Brazil), at the geographical coordinates $16^{\circ} 35^{\prime} 59.1^{\prime}$ ' S, 49 $9^{\circ} 16^{\prime} 47.1^{\prime} \mathrm{W}$, and $730 \mathrm{~m}$ of altitude, totaling $6,400 \mathrm{~m}^{2}$ of area. The incisions, $10 \mathrm{~cm}$ long and $2 \mathrm{~cm}$ deep, were performed in triplicate on each tree branch on February $\left(26^{\circ} \mathrm{C}\right.$ and $13 \mathrm{~mm}$ of rainfall) and September $\left(25.7{ }^{\circ} \mathrm{C}\right.$, without rainfalls) of 2016 (Evaporimetric Station, 2016). After 15 days, the exudate nodes were collected with a spatula and stored in an amber bottle. The exsiccate of the species Anacardium othonianum Rizz. is deposited at the Herbarium of the Universidade Estadual de Goiás under the number 10,993.

The exudate nodules were ground and dissolved in $20 \%(\mathrm{w} / \mathrm{v})$ distilled water. The mixture was kept at room temperature for $24 \mathrm{~h}$ for complete dissolution. This mixture was filtered through nylon ( 90 threads), and then added to absolute ethanol at a ratio of 1:3. The suspension was kept at room temperature for $24 \mathrm{~h}$. After decantation, the supernatant was discarded, and the precipitate was washed with absolute ethanol and filtered through nylon (110 threads). This procedure yielded $75 \%$ polysaccharide, named as PEJU-GO, which was dried outdoors and protected from sunlight exposure, crushed and then stored in hermetically sealed bottles at $4{ }^{\circ} \mathrm{C}$ until use.

\subsection{Acquisition and characterization of the sodium periodate-treated arboreal cashew polysaccharide (PEJUp)}

A mixture containing of $0.05 \mathrm{~g}$ PEJU, $2.0 \mathrm{~mL}$ of $0.1 \mathrm{~mol} \mathrm{~L}^{-1}$ sodium periodate and $10 \mathrm{~mL}$ of $0.1 \mathrm{~mol} \mathrm{~L}^{-1}$ sodium phosphate buffer $\mathrm{pH} 7.0$ was stirred for $30 \mathrm{~min}$ at $23{ }^{\circ} \mathrm{C}$ following the method proposed by Pappas et al. ${ }^{[12]}$ Then, the complex sodium periodate-treated polysaccharide (PEJUp) was precipitated using absolute ethanol (1:3, v/v) at $10^{\circ} \mathrm{C}$ for $24 \mathrm{~h}$. The supernatant was discarded and the precipitate (PEJUp) was dried at $23{ }^{\circ} \mathrm{C}$. The powder obtained was ground and stored in amber flasks at $4{ }^{\circ} \mathrm{C}$ until use.

The morphological analysis of PEJUp was performed by scanning electron microscopy (Shimadzu, model SSx 550, Japan), with magnifications from 50 to $1,000 x$.
PEJUp samples were analyzed by infrared spectrometry (FTIR) using KBr pellets (Bomn FT-IR model MB100, USA), and scanned within the range of 4,000 to $500 \mathrm{~cm}^{-1}$.

The determination of the crystalline phases of the samples was evaluated by X-ray diffraction (XRD) measurements on a D8 Discover diffractometer (Bruker, Germany), under rotation of $15 \mathrm{rpm}$ and a range of $2^{\circ}$ from $5^{\circ}$ to $70^{\circ}$ and a step of $0.02^{\circ}[13]$.

The thermal stability of the PEJUp was evaluated by thermogravimetric analysis using the methodology of Lomonaco $^{[14]}$. The samples were subjected to heating ramps of $25^{\circ} \mathrm{C}$ to $500{ }^{\circ} \mathrm{C}$ at a rate of $3{ }^{\circ} \mathrm{C} \mathrm{min}-1$ using DTG- $60 \mathrm{H}$ (Shimadzu, China).

\subsection{Measurement of peroxidase activity (Horseradish peroxidase, $H R P$ ) and enzyme immobilization}

The enzyme activity was determined by the method of Halpin and Lee ${ }^{[15]}$. In test tubes, $2.4 \mathrm{~mL}$ of pyrogallol (1.6 mg mL $\mathrm{m}^{-1}$ ), prepared in $0.1 \mathrm{~mol} \mathrm{~L}^{-1}$ sodium phosphate buffer $\mathrm{pH} 6.0$, were incubated at $23{ }^{\circ} \mathrm{C}$ with $0.1 \mathrm{~mL}$ of the enzyme solution (29 U) prepared in the same buffer. Hydrogen peroxide $(0.5 \mathrm{~mL})$ at $0.05 \mathrm{~mol} \mathrm{~L}^{-1}$ was added and after one minute, the absorbance was measured at $420 \mathrm{~nm}$. One enzyme unit (U) was considered as the amount of peroxidase that increases 0.1 absorbance $\mathrm{min}^{-1}$ of reaction under the assay conditions.

HRP was immobilized by physical adsorption and by attachment using sodium periodate, obtaining more active points between the support and the enzyme. The best retention of enzymatic activity was conducted at different immobilization $\mathrm{pH}$, days of storage and reuse using $29 \mathrm{U}$ of enzymatic solution in $10 \mathrm{mg}$ PEJU and $15 \mathrm{mg}$ PEJUp under gentle agitation $(720 \mathrm{rpm})$ for $2 \mathrm{~h}$ at $4{ }^{\circ} \mathrm{C}$. Then, the PEJU-HRP and PEJUp-HRP were precipitated using absolute ethanol at $4{ }^{\circ} \mathrm{C}$, centrifuged, and tested for immobilized enzymatic activity. The activity test consisted of adding $1.4 \mathrm{~mL}$ of $0.1 \mathrm{~mol} \mathrm{~L}^{-1}$ sodium phosphate buffer $\mathrm{pH}$ 6.0, $0.5 \mathrm{~mL}$ of hydrogen peroxide $0.05 \mathrm{~mol} \mathrm{~L}^{-1}$ and $1.0 \mathrm{~mL}$ of $0.07 \mathrm{~mol} \mathrm{~L}^{-1}$ pyrogallol to the PEJU-HRP and to the PEJUp-HRP complex. After one minute of reaction, readings were taken according to Halpin and Lee ${ }^{[15]}$.

\subsection{The potential use of free and immobilized peroxidase for phenolic waste degradation}

The tests with phenolic compounds and agroindustrial effluents (Wastewater Treatment Center and Textile effluent) were carried out based on the methodology of Akhtar and Husain ${ }^{[16]}$ and Ramalho et al. ${ }^{[17]}$. The effluent samples were collected at the Wastewater Treatment Station (WTS) in the Anápolis Agroindustrial District (DAIA) (16 $30^{\prime}$ 'S and 49 $00^{\prime} \mathrm{W}$ ), and at Cia Hering in São Luís de Montes Belos, Goiás state, Brazil (16 ${ }^{\circ} 52^{\prime} \mathrm{S}$ and $\left.50^{\circ} 32^{\prime} \mathrm{W}\right)$. The organic load after $24 \mathrm{~h}$ of collection in the raw sewage, according to the Department of the Environment of the DAIA, is $3,750 \mathrm{~kg}$ BOD.day ${ }^{-1}$.

The free HRP, the PEJU-HRP and the PEJUp-HRP complexes were incubated with the following phenolic compounds: pyrogallol, catechol, phenol, bromophenol, and nitrophenol $\left(1.0 \mathrm{mmol} \mathrm{L}^{-1}\right)$, as well as effluents (WTS and 
Textiles), with addition of hydrogen peroxide $\left(0.05 \mathrm{~mol} \mathrm{~L}^{-1}\right)$. The mixture remained at $23{ }^{\circ} \mathrm{C}$ for $10 \mathrm{~min}$, and the residual concentration of phenols were measured using the methodology of Lowry et al. ${ }^{[18]}$. For the best-immobilized complexes against the removal of phenols, toxicity tests on Artemia salina ${ }^{[19]}$ and Allium cepa roots $^{[20]}$ were performed. The mitotic index (MI) and the frequency of mitotic cycle abnormalities (ACM) in the slides were evaluated. MI was determined using the Equation 1:

$$
M I=N C M \div T N C \times 100
$$

where NCM corresponds to the number of cells in mitotic division, and TNC corresponds to the total number of cells analyzed.

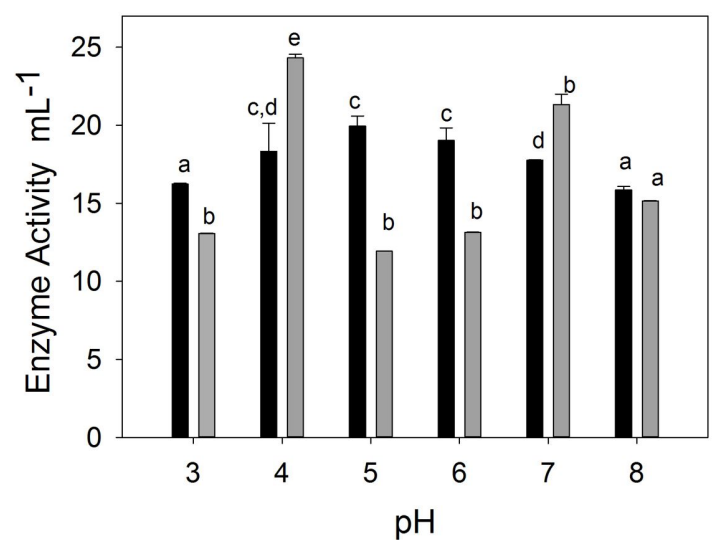

Figure 1. Immobilization of horseradish peroxidase on PEJU and PEJUp. Effect of $\mathrm{pH}$. Black columns represent physically adsorbed HRP (PEJU-HRP). Gray columns show immobilization after sodium periodate treatment (PEJUp-HRP). Significant differences appear by distinct letters when $\mathrm{p}<0.05$ by test Tukey.

\subsection{Statistical analyses}

Statistical analyses were performed using the R Studio program (package MASS) ${ }^{[21]}$. A two-way ANOVA was used to determine the statistical significance of the effects of the treatments on the immobilization processes with a posteriori Tukey test $(\mathrm{p}<0.05)$. The two-way ANOVA determined the statistical significance of $\mathrm{pH}$ effects on both treatments (represented in Figure 1 by different letters). In this analysis, the immobilization $\mathrm{pH}$ was used as a treatment with two levels: PEJU and PEJUp, representing physical adsorption and weak bond interactions (such as hydrogen bonds), respectively. The possible results are (1) the effect of the chemical treatment alone (immobilization $\mathrm{pH}$ ) in case of a statistical significant size effect: it means that there is a difference between the tested chemical treatments; (2) the effect of the immobilization treatment alone in case of a statistical significant size effect: it means that there is a difference between the immobilization treatments tested; and (3) the joint effect for both treatments in case of a statistical significant size effect: it means that the effect observed depends on each level of variables tested.

\section{Results and Discussions}

\subsection{Characterization of PEJUp}

The scanning electron microscopy (Figure 2) of the PEJUp presented a characteristic aspect for the treatment of polysaccharides with sodium periodate: irregular and amorphous fragments and dispersed mass, strongly influencing its stability in the aqueous system ${ }^{[22]}$. The reaction with sodium periodate results in the appearance of aldehyde carbonyls in vicinal carbons. It is widely used as a routine method for the elucidation of complex carbohydrate structures. This recent application has helped to interpret the fundamental
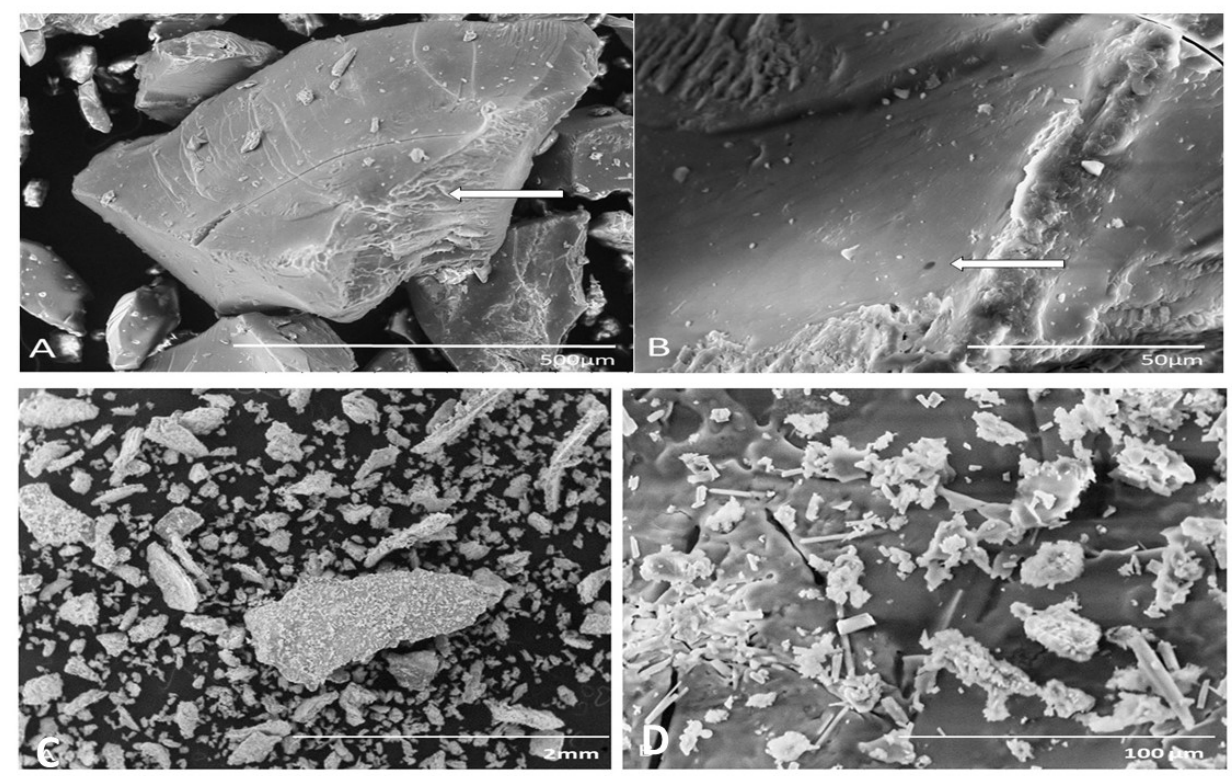

Figure 2. Electron micrograph of Cerrado-arboreal cashew (A. othonianum Rizz.) polysaccharide, PEJU (A: 200x and B: 1000x) and treated in sodium periodate, PEJUp (C: 200x and D: 1000x). 
structures of some polysaccharides, such as cellulose, starch, xylan, and glycogen ${ }^{[23]}$.

The infrared spectra of the PEJU ${ }^{[1]}$ have polysaccharide bands, such as those within the range of 3,000 to 2,840 $\mathrm{cm}^{-1}$ (OH stretch) and close to $2,936 \mathrm{~cm}^{-1}$. This indicates that this material contains sugars such as galactose, arabinose, and rhamnose. It is different from that presented for PEJUp (Figure 3A), a region in which such vibrations did not appear due to the cleavage process of glucosidic bonds. The absorbance at about $1,740 \mathrm{~cm}^{-1}$ is characteristic of carbonyl groups, while the band around $880 \mathrm{~cm}^{-1}$ is generally assigned to the formation of hemiacetal bonds between the aldehyde groups and neighbor hydroxyl groups. Absorptions within the 1,500 to $600 \mathrm{~cm}^{-1}$ regions are associated with axial and angular deformations of $\mathrm{C}-\mathrm{O}, \mathrm{C}-\mathrm{N}, \mathrm{C}-\mathrm{C}$, and $\mathrm{C}-\mathrm{X}$ bonds. In the presence of sodium periodate, the oxidation of some biopolymers (e.g., xanthan gum) is characterized by the specific cleavage of the $\mathrm{C} 2$ and $\mathrm{C} 3$ bond of residues, resulting in the formation of aldehyde groups ${ }^{[12]}$. Observing both materials, we found sharp bands in the regions between 1,400 and $800 \mathrm{~cm}^{-1}$ in the FTIR spectra of the oxidized periodate (PEJUp) due to $\mathrm{OH}$ groups exposure after oxidation.

In the X-ray diffraction pattern of PEJUp (Figure 3B), the presence of these semi-defined peaks can be caused by a high sugar content in the sample and by the fragmentation process after treatment with sodium periodate ${ }^{[24]}$. The patterns showed the highest peak at $15.22^{\circ}(100 \%$ relative intensity (RI)), followed by $22.4^{\circ}(81 \% \mathrm{RI}), 25.9^{\circ}$ (80\% RI) and $12.08^{\circ}(65.9 \% \mathrm{RI})$, indicating the amorphous phase of the material. The increase in the amorphous percentage may be related to a change in the chain configuration. During the oxidation, there are breaks in chemical bonds and chain breaks ${ }^{[25]}$. The crystalline and amorphous material forms may show differences in particle size and shapes, physical-chemical properties, chemical stability, water solubility and hygroscopicity ${ }^{[26]}$. The predominance of large and diffuse peaks in X-ray diffractograms indicates amorphous and crystalline materials with a considerable and semi-defined noise ${ }^{[9]}$.

The thermogravimetric analysis (TGA) performed to evaluate the thermal stability of the polysaccharide (PEJUp) is shown in Figure 3C. The decomposition of PEJUp occurred in two stages: the first between 50 and $100{ }^{\circ} \mathrm{C}$ (maximum at $80{ }^{\circ} \mathrm{C}$ ), which, in line with the characteristic of sugar chain breakdown caused by sodium periodate, suggests the beginning of carbon skeleton decomposition for the polysaccharide with this treatment. The second peak was observed between 320 and $500{ }^{\circ} \mathrm{C}$ (maximum at $500{ }^{\circ} \mathrm{C}$ ), probably due to depolymerization of $\mathrm{CO}$ and $\mathrm{CH}_{4}$ bonds. Guo et al. ${ }^{[27]}$ found a similar process in a study with xanthan gum. Silva et al. ${ }^{[1]}$ reported a decomposition behavior for PEJU with a higher thermostability, the first between 280 and $300{ }^{\circ} \mathrm{C}$ (maximum $300^{\circ} \mathrm{C}$ ) and the second between 300 and $490{ }^{\circ} \mathrm{C}$ (maximum $430{ }^{\circ} \mathrm{C}$ ). Mothé and $\mathrm{Rao}^{[28]}$ verified only a decomposition step with the maximum temperature around $300{ }^{\circ} \mathrm{C}$ for the polysaccharide of $A$. occidentale. Residual masses (around $600{ }^{\circ} \mathrm{C}$ ) were verified in some polysaccharides of galactoxyloglucans ${ }^{[29]}$, guar gum ${ }^{[30]}$ and carboxymethylated cashew gum ${ }^{[31]}$.

\subsection{Peroxidase immobilization in different ways}

The immobilization assays of Cerrado arboreal polysaccharides by HRP physically adsorbed resulted in $72.4 \%$ of immobilization yield ( $21 \mathrm{U}$ ) and, by using sodium
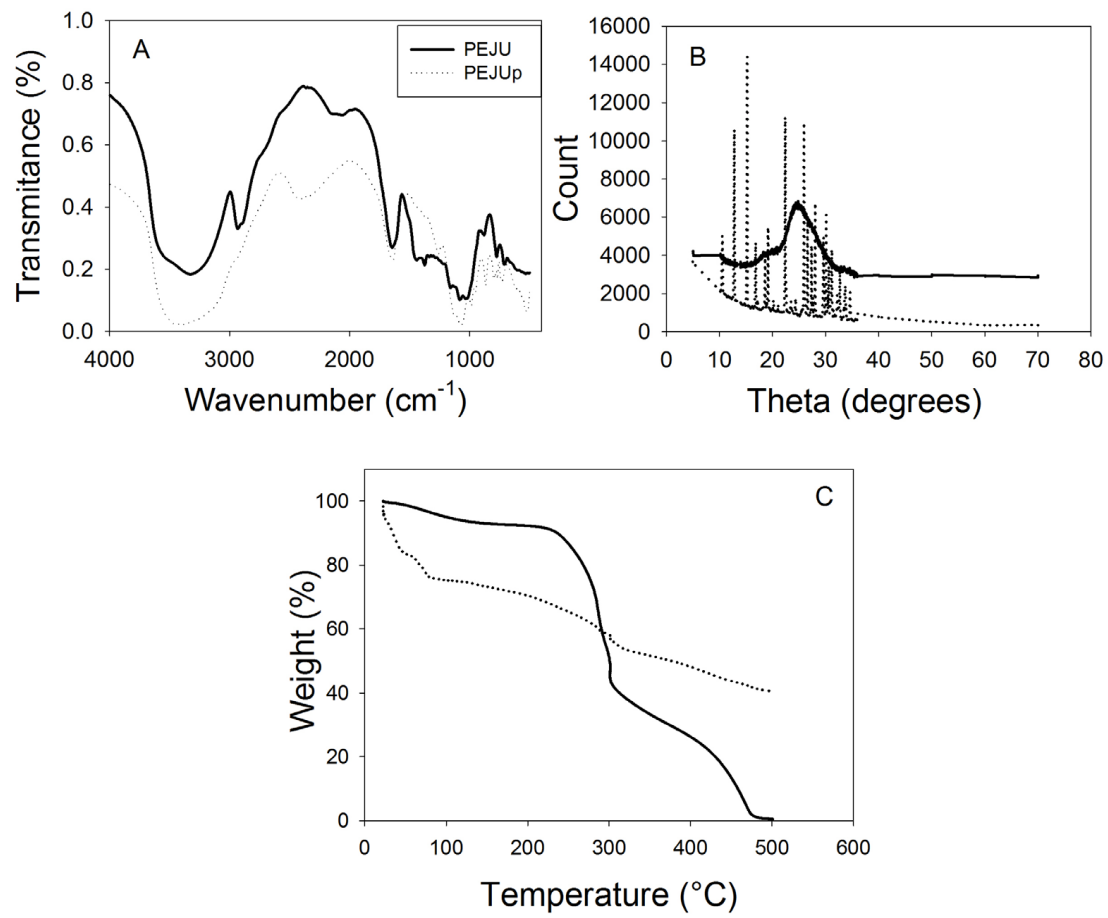

Figure 3. Characterization of Cerrado-arboreal cashew polysaccharide (A. othonianum Rizz.) treated in sodium periodate. (A) Infrared spectrum of (4000 to $\left.500 \mathrm{~cm}^{-1}\right)$; (B) Diffractogram; (C) Thermogravimetric analysis. 
periodate as a treatment, in $93.1 \%$ of immobilization yield (27 U), when there were optimal conditions.

Figure 1 shows the influence of $\mathrm{pH}$ on the immobilization process for PEJU-HRP and PEJUp-HRP. Using the physical adsorption method, the $\mathrm{pH} 7.0$ was the best condition for HRP immobilization, followed by $\mathrm{pH} 4.0,5.0$ and 6.0. On the other hand, if the choice is periodate-treated PEJU (PEJUp), there are two suitable $\mathrm{pH}$ conditions for HRP immobilization: at 4.0 and 7.0. According to Pappas et al. ${ }^{[12]}$, sodium periodate oxidases the pyranosidic structure, opening the ring to form two adjacent carbonyl groups. This chemical attack on PEJU probably destabilized the polysaccharide chain, resulting in such randomized behavior.

Gomez-Estaca et al. ${ }^{[32]}$ studied the effects of $\mathrm{pH}$ on A. occidentale polysaccharide-protein interactions. According to the analysis of potential zeta, the authors found PEJU as the negatively charged polymer in the $\mathrm{pH}$ range 2.0 to 8.0 . Similarities between $A$. ocidentale and $A$. othonianum polysaccharides in composition and structure may suggest that, from $\mathrm{pH} 4.0$ to $\mathrm{pH} 7.0$, there are negative charges along the polymer that favors the immobilization via adsorption in a large $\mathrm{pH}$ range ${ }^{[11]}$.

Depending on the load properties of the immobilization carrier, the ideal pH may undergo significant changes. The ideal $\mathrm{pH}$ of an anionic support-bound enzyme shifts to higher values (however, immobilization in a cationic matrix may exert the opposite effect, which justifies the result found for immobilization via sodium periodate-treated PEJUp: $24.3 \mathrm{U}$ at $\mathrm{pH}$ 4.) The monitoring of $\mathrm{pH}$ in industrial processes (feed, pharmaceutical, water and effluent treatments) is essential for the effectiveness of the process $^{[33]}$. Thus, PEJU as a support is able to retain HRP activity in both acidic and neutral media, which allows its application for different reaction purposes.

The stability of PEJU-HRP and PEJUp-HRP was analyzed for 30 days of storage at $4{ }^{\circ} \mathrm{C}$ without addition of any enzymatic stabilizer in either of the two complexes (Table 1). For immobilization by physical adsorption, over $70 \%$ of enzyme activity remained after 30 days. Bayramoğlu and $\mathrm{Arica}^{[34]}$ obtained over $84 \%$ of remaining peroxidase activity, but the authors used magnetic methacrylate beads activated using glutaraldehyde. The modified magnetic support, according the authors, was responsible for the enhance in the enzyme stability in comparison to free HRP. Otherwise, polysaccharides can play fundamental roles in enzymatic stability through electrostatic, dipole-ionic or hydrophobic interactions with the protein structure ${ }^{[3]}$.

For PEJUp, after 15 days, the remained activity was only $6 \%$ under the same storage conditions as PEJU-HRP. Considering the degradation and instability (Figure 3B and 3C) of the PEJUp structure caused by sodium periodate oxidation, the physical peroxidase adsorption was the best choice for storage conditions in the immobilization of HRP using PEJU.

Table 1 also shows the applicability and reuse of immobilized complexes. After three repeated runs, the PEJU-HRP without the addition of any stabilizer retained about $18 \%$ of its initial activity. The PEJUp-HRP, prepared in the same condition as the the adsorbed enzyme, had the double of activity retention (35\%), totaling eight use cycles (retention of $9 \%$ of the initial activity). The remaining activity is lower than that reported for macroporous glucosidic polymers $(50 \% \text { activity retained after four cycles })^{[35]}$ or microgels $(50 \% \text { retained activity after five cycles })^{[36]}$ or even through the sodium periodate-treated support ( $9 \%$ of retained activity after eight uses), all of which are covalent strategies.

\subsection{Industrial wastewater treatment using immobilized $H R P$ and evaluation of residual toxicity}

The ability of HRP, PEJU-HRP and PEJUp-HRP complexes to remove phenols is evidenced by the data in Figure $4 \mathrm{~A}$ and $4 \mathrm{~B}$. The immobilized complexes removed

Table 1. Stability - shelf life and reuse - of PEJU-HRP and PEJUp-HRP complexes.

\begin{tabular}{lccc}
\hline & & \multicolumn{2}{c}{ Remained activity (\%) } \\
\cline { 2 - 3 } Time (days of storage) & 1 & PEJU-HRP & PEJP-HRP \\
\cline { 2 - 3 } & 3 & 100 & 71.4 \\
& 6 & 100 & 25.6 \\
& 9 & 100 & 20.6 \\
& 12 & 82 & 6.4 \\
Cycles of use & 15 & 82.9 & 1.1 \\
& 18 & 82 & 0.9 \\
& 21 & 81.7 & 0.9 \\
& 24 & 75.1 & 0.9 \\
& 27 & 76.3 & 0.6 \\
& 30 & 70.5 & 100 \\
& 1 & 100 & 82 \\
& 2 & 65 & 48 \\
& 3 & 18 & 35 \\
& 4 & 6 & 16 \\
\end{tabular}


Table 2. Evaluation of toxicity, citotoxicity and genotoxicity over Allium cepa roots by different PEJU complexes and phenolic waste.

\begin{tabular}{lccc}
\hline \multicolumn{1}{c}{ Treatments } & Toxicity (\%) & Citotoxicity (\%) & Genotoxicity (\%) \\
\hline Distilled water & 0 & 0 & 0 \\
Sodium azide $\left(0.02 \mathrm{~g} \mathrm{~mL}^{-1}\right)$ & 63.5 & 25.9 & 47.0 \\
PEJU $\left(10 \mathrm{mg} \mathrm{mL}^{-1}\right)$ & 0 & 27.2 & 9.4 \\
WTS & 90 & 32.4 & 34.0 \\
PEJU-HRP-WTS & 0 & 31.5 & 18.9 \\
\hline
\end{tabular}
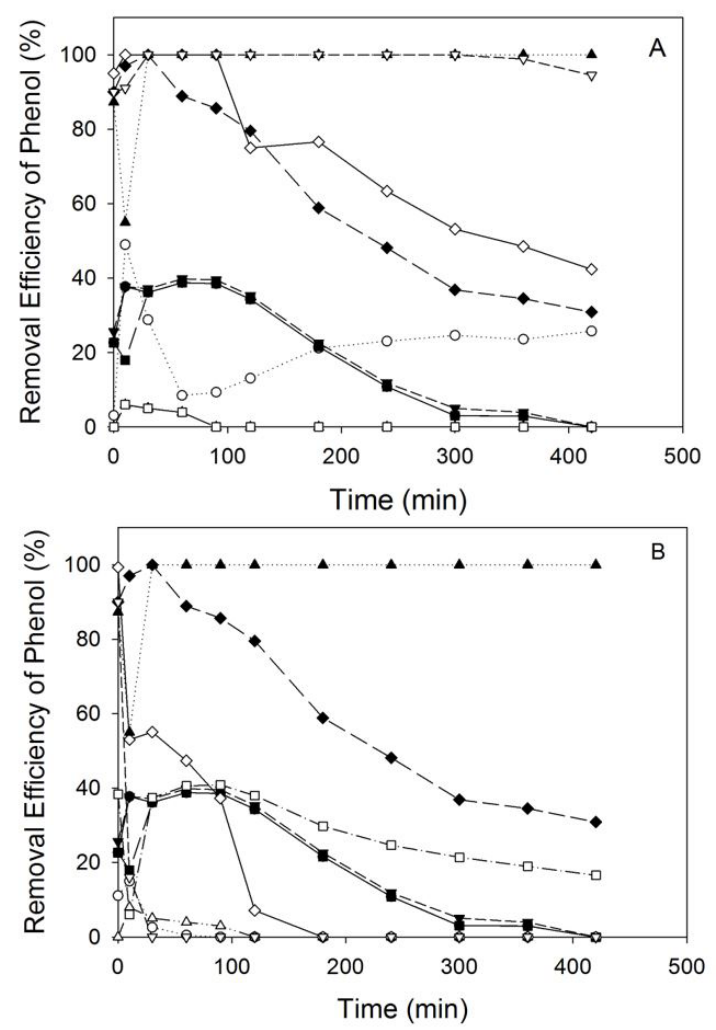

Figure 4. Phenol efficiency removal (\%) of horseradish peroxidase (HRP) and immobilized complexes PEJU-HRP (A) and PEJUp-HRP (B) in the phenolics effluent samples. The removal efficiency of free HRP are the closed symbols and the PEJU-HRP or PEJUp-HRP are the open symbols. --- -- pyrogallol; -- $\nabla$-- phenol; -- $\square$-- bromophenol; -- $\diamond$-- textile effluent; -- $\triangle$-- WTS effluent treatment.

phenolic compounds and presented a similar or higher performance compared to the free enzyme. Catechol and nitrophenol were not removed by any of the tested enzyme forms.

For the phenolic prepared solutions, free HRP and PEJU-HRP removed $26 \%$ of pyrogallol up to $120 \mathrm{~min}$ (Figure 4A). After this time, the free peroxidase decreases its capacity, while the PEJU-HRP continues the same profile of degradation. This might be explained due to inactivation and/or inhibition on free enzyme caused by interactions between phenoxyl radicals or phenolic polymers produced during catalysis ${ }^{[37]}$. Approximately $38 \%$ of bromophenol could be removed by free HRP and by PEJUp-HRP up to $120 \mathrm{~min}$, but the immobilized complex remained more stable than the free enzyme (Figure 4B).
All enzyme forms degraded the industrial effluents (Figure 4A and 4B). PEJU-HRP (Figure 4A) showed a removal efficiency of $94 \%$ from the WTS, and $100 \%$ of the textile effluent. If the incubation time is considered, the immobilized form of peroxidase was more stable and continuously removed phenols from complex mixtures over time. This is in accordance to Tatsumi et al. ${ }^{[38]}$, who used immobilized HRP on cellulose via oxidation through periodate, and removed more than $80 \%$ of phenol from aqueous solutions using continuous reactors.

Figure 4 also shows that the maximum reaction time for phenol removal by immobilized complexes was up to $30 \mathrm{~min}$. The free enzyme needed $90 \mathrm{~min}$ to achieve the maximum of phenol removal capacity. The advantage of an immobilized enzyme in such processes lies not only in its stability: the preparation maintains a remarkable discoloration activity when compared to the free form ${ }^{[11]}$.

Table 2 shows the results of toxicity tests by incubating the roots of Allium cepa in PEJU complexes and controls. Bilal et al. ${ }^{[8]}$, evaluating the performance of immobilized MnPeroxidase for the treatment of wastewater, discussed the biological toxicity of degraded compounds after waste treatment.

Toxic agents must reduce more than $50 \%$ the germination index of Allium cepa in relation to the negative control ${ }^{[20]}$. This indicates that the effluent from WTS is a toxic material with a reduction effect $(\mathrm{p}<0.05)$ higher than the negative control (sodium azide $0.02 \mathrm{~g} \mathrm{~mL}^{-1}(63.5 \%)$ ). The non-toxicity of PEJU is evident by growth averages: it is contained in the immobilized enzyme complex, and the treated effluent reflects this non-toxic material characteristic. The cytotoxic evaluation is based on the change in the mitotic index (MI) of the different treatments. Based on Table 2, the solutions containing PEJU did not promote cytotoxic alterations when compared to the negative control (water) (mitotic index lower than 22\%). In the literature, cytotoxic interference occurs when the substance is capable of inhibiting $22 \%$ of the mitotic index in relation to the negative control and, at a greater amount of inhibition, over $50 \%{ }^{[19]}$. Normal mitosis is noted when both negative control and PEJU were incubated within Allium cepa roots. By using the wastewater or only free HRP replacing PEJU, there is a genotoxic effect of those substances (Table 2). PEJU, as a support for HRP immobilization, was able to reduce the genotoxicity of the industrial effluent by $15.1 \%$ (Table 2 ). The genotoxicity test aims to identify if the analyzed substance affects key cell processes, such as duplication and gene transcription ${ }^{[39]}$. This provided efficiency not only to the immobilization itself, but also to its contribution to the process of environmental restoration as an agent of bioremediation.

The results of atoxicity of this material at the investigated concentrations against Artemia salina are promising 
and corroborate the potential of this material for future biotechnological applications of these polysaccharides (in the food industry as thickening agents, in the pharmaceutical industry, and as adjuvants in the manufacture of drugs).

\section{Conclusions}

The information obtained in this study indicates the Cerrado-arboreal cashew (Anacardium othonianum Rizz.) polysaccharide as a promising source for biotechnological application, especially the use of this material as a support for the immobilization of peroxidases in two ways: physical adsorption and chemical, non-covalent bond. Due to the instability of the support during the sodium periodate oxidation process, the PEJU-HRP showed a better action. It is stable in storage conditions. It can be repeatedly used for the enzymatic activity in laboratory practice. It has a homogeneous behavior in different $\mathrm{pH}$ conditions. Finally, it is a low-cost, non-toxic substance and extracted in a sustainable way. In addition to these applications, the removal of phenolic compounds through the immobilized enzyme system showed a high efficiency for both immobilization methods proposed. This material plays a significant role as a more stable, recoverable industrial biocatalyst with a low or no toxicity in tests with bioindicators, such as Artemia salina and Allium cepa roots. It is reusable in various other industrial, biotech, pharmaceutical and medical complexes.

The technological interest in cashew polysaccharides, especially this Cerrado species, is related to its rheological characteristics and biodegradability. The possibility of using it as a low-cost substitute for other polysaccharides is attractive, and may expand the possibilities of using this material and promote its commercial exploitation by communities associated with cashew cultivation.

\section{Acknowledgements}

The authors are grateful to the Regional Centre for Technological Development and Innovation (CRTI). They thank the employees of the DAIA Waste Treatment Station and the Cia Hering Work Safety Engineer (Alessandro de Paula Cardoso) for the effluent concession for analysis. Finally, the authors thank The Coordination for the Improvement of Personnel Higher Education (CAPES) and the program of research incentive grants (PROBIP/UEG).

\section{References}

1. Choong, G. Y. H., \& Focattis, D. S. A. (2016). A method for the determination and correction of the effect of thermal degradation on the viscoelastic properties of degradable polymers. Polymer Degradation and Stability Journal, 130, 182-188. http://dx.doi. org/10.1016/j.polymdegradstab.2016.06.018.

2. Akhtar, M., \& Ding, R. (2017). Covalently cross-linked proteins $\&$ polysaccharides: formation, characterization and potential applications. Current Opinion in Colloid \& Interface Science, 28, 31-36. http://dx.doi.org/10.1016/j.cocis.2017.01.002.

3. Silva, T. M., Santiago, P. O., Purcena, L. L. A., \& Fernandes, K. F. (2010). Study of the cashew gum polysaccharide for the horseradish peroxidase immobilization: structural characteristics, stability and recovery. Materials Science and Engineering $C$, 30(4), 526-530. http://dx.doi.org/10.1016/j.msec.2010.01.016.
4. Correa, G. C., Naves, R. V., Rocha, M. R., Chaves, L. J., \& Borges, J. D. (2008). Physial determinations in fruit and seeds of Baru (Dipteryx alata Vog.), Cajuzinho (Anacardium othonianum Rizz.) and Pequi (Caryocar brasiliense Camb.) aiming genetic breeding. Bioscience Journal, 24(4), 42-47. Retrieved in 2019, January 30, from http://www.seer.ufu.br/ index.php/biosciencejournal/article/view/6628/4356

5. Klibanov, A. M., Alberti, B. N., Morris, E. D., \& Felshin, L. M. (1980). Enzymatic removal of toxic phenols and anilines from wastewaters. Journal of Applied Biochemistry, 2, 414421. Retrieved in 2019, January 30, from https://www.osti. gov/biblio/6449569

6. Niu, J., Xu, J., Dai, Y., Xu, J., Guo, H., Sun, K., \& Liu, R. (2013). Immobilization of horseradish peroxidase by electrospun fibrous membranes for adsorption and degradation of pentachlorophenol in water. Journal of Hazardous Materials, 246-247, 119-125. http://dx.doi.org/10.1016/j.jhazmat.2012.12.023. PMid:23295768.

7. Alarcón-Payán, D. A., Koyani, R. D., \& Vazquez-Duhalt, R. (2017). Chitosan-based biocatalytic nanoparticles for pollutant removal from wastewater. Enzyme and Microbial Technology, 100, 71-78. http://dx.doi.org/10.1016/j.enzmictec.2017.02.008. PMid:28284314.

8. Bilal, M., Asgher, M., Iqbal, M., Hu, H., \& Zhang, X. (2016). Chitosan beads immobilized manganese peroxidase catalytic potential for detoxification and decolorization of textile effluent. International Journal of Biological Macromolecules, 89, 181-189. http://dx.doi.org/10.1016/j.ijbiomac.2016.04.075. PMid:27130652.

9. Akhtar, S., \& Husain, Q. (2006). Potential applications of immobilized bitter gourd (Momordica charantia) peroxidase in the removal of phenols from polluted water. Chemosphere, 65(7), 1228-1235. http://dx.doi.org/10.1016/j.chemosphere.2006.04.049. PMid:16764905.

10. Karim, Z., Adnan, R., \& Husain, Q. (2012). A $\beta$-cyclodextrinechitosan complex as the immobilization matrix for horseradish peroxidase and its application for the removal of azo dyes from textile effluent. International Biodeterioration \& Biodegradation, 72, 10-17. http://dx.doi.org/10.1016/j.ibiod.2012.04.008.

11. Silva, T. M., Souza, E. R. B., de Paula, J. A. M., Borges, L. L., \& Caramori, S. S. (2017). Chemical characterization and biotecnological application of cashew tree polyssacharide of Brazilian Cerrado (Anacardium othonianum Rizz.), Anarcadiaceae, Fronteiras: journal SocietyTechnology. Environmental Sciences, 6(3), 230-246. http://dx.doi.org/10.21664/2238-8869.2017v6i3. p230-246.

12. Pappas, A. C., Stalikas, C. D., Fiamegos, Y. C., \& Karayannis, M. I. (2002). Determination of hydrogen peroxide by using a flow injection system of immobilized peroxidase and long pathlength capillary spectrophotometry. Analytica Chimica Acta, 455(2), 305-313. http://dx.doi.org/10.1016/S00032670(01)01600-2.

13. Pang, J., Jian, W., Wang, L., Wu, C., Liu, Y., He, J., \& Tang, X. (2012). X-ray photoelectron spectroscopy analysis on surface modification of Konjac glucomannan membrane by nitrogen plasma treatment. Carbohydrate Polymers, 17(1), 369-372. http://dx.doi.org/10.1016/j.carbpol.2011.12.013.

14. Lomonaco, D., Maia, F. J. N., Clemente, C. S., Mota, J. P. F., Costa, A. E., \& Mazzetto, S. E. (2012). Thermal studies of new biodiesel antioxidants synthesized from a natural occurring phenolic lipid. Fuel, 97, 552-559. http://dx.doi.org/10.1016/j. fuel.2012.01.059.

15. Halpin, B. E., \& Lee, C. Y. (1987). Effect of blanching on enzyme activity and quality changes in green peas. Journal of Food Science, 52(4), 1002-1005. http://dx.doi. org/10.1111/j.1365-2621.1987.tb14261.x. 
16. Akhtar, M., \& Ding, R. (2017). Covalently cross-linked proteins \& polysaccharides: Formation, characterisation and potential applications. Current Opinion in Colloid \& Interface Science, 28, 31-36. http://dx.doi.org/10.1016/j.cocis.2017.01.002.

17. Ramalho, R. P. R. S., Scalize, P. S., \& Caramori, S. S. (2016). Peroxidase of Brazilian Cerrado grass as an alternative for agro industrial waste treatment. Ambiente \& Água, 11(1), 50-59. http://dx.doi.org/10.4136/ambi-agua.1735.

18. Lowry, O. H., Rosebrough, N. J., Farr, A. L., \& Randall, R. J. (1951). Protein measurement with the Folin-Phenol reagent. The Journal of Biological Chemistry, 193(1), 265-275. PMid:14907713.

19. Molina-Salinas, G. M., \& Said-Fernández, S. (2006). A modified microplate cytotoxicity assay with brine shrimp larvae (Artemia salina). Pharmacologyonline, 3, 633-638.

20. Fiskesjö, G. (1985). The Allium test: a standard in environmental monitoring. Hereditas, 102(1), 99-112. http://dx.doi. org/10.1111/j.1601-5223.1985.tb00471.x. PMid:3988545.

21. R Core Team (2018). R: a language and environment for statistical computing. Vienna: R Foundation for Statistical Computing. Retrieved in 2019, January 30, from https:// www.R-project.org/

22. Kristiansen, K. A., Potthast, A., \& Christensen, B. E. (2010). Periodate oxidation of polysaccharides for modification of chemical and physical properties. Carbohydrate Research, 345(10), 1264-1271. http://dx.doi.org/10.1016/j.carres.2010.02.011. PMid:20227684

23. Vold, I. M. N., \& Christensen, B. E. (2005). Periodate oxidation of chitosans with different chemical compositions. Carbohydrate Research, 340(4), 679-684. http://dx.doi.org/10.1016/j. carres.2005.01.002. PMid:15721340.

24. Wu, C., Peng, S., Wen, C., Wang, X., Fan, L., Deng, R., \& Pang, J. (2012). Structural characterization and properties of konjac glucomannan/curdlan blend films. Carbohydrate Polymers, 89(2), 497-503. http://dx.doi.org/10.1016/j.carbpol.2012.03.034. PMid:24750750.

25. Andrade, K. C. S., Carvalho, C. W. P., \& Takeiti, C. Y. (2013). Cashew gum (Anacardium occidentale): evaluation of chemical and physical changes by thermoplastic extrusion. Polimeros: Ciencia e Tecnologia, 23(5), 667-671. http://dx.doi.org/10.4322/ polimeros.2013.004.

26. Cano-Chauca, M., Stringheta, P. C., Ramos, A. M., \& CalVidal, J. (2005). Effect of the carriers on the microstructure of mango powder obtained by spray drying and its functional characterization. Innovative Food Science \& Emerging Technologies, 6(4), 420-428. http://dx.doi.org/10.1016/j. ifset.2005.05.003.

27. Guo, J., Li, X., Mu, C., Zhang, H., Qin, P., \& Li, D. (2013). Freezing ethawing effects on the properties of dialdehyde carboxymethyl cellulose crosslinked gelatin-MMT composite films. Food Hydrocolloids, 33(2), 273-279. http://dx.doi. org/10.1016/j.foodhyd.2013.04.004.

28. Mothé, C. G., \& Rao, M. A. (2000). Thermal behavior of gum arabic incomparison with cashew gum. Thermochimica Acta, 357-358, 9-13. http://dx.doi.org/10.1016/S0040-6031(00)00358-0.

29. Zohuriaan, M. J., \& Shokrolahi, F. (2004). Thermal studies on natural and modified gums. Polymer Testing, 23(5), 575-579. http://dx.doi.org/10.1016/j.polymertesting.2003.11.001.
30. Varma, A. J., Kokane, S. P., Pathak, G., \& Pradhan, S. D. (1997). Thermal behavior of galactomannan guar gum and its periodate oxidation products. Carbohydrate Polymers, 32(2), 111-114. http://dx.doi.org/10.1016/S0144-8617(96)00155-5.

31. Silva, F. E. F., Batista, K. A., Di-Medeiros, M. C. B., Silva, C. N. S., Moreira, B. R., \& Fernandes, K. F. (2016). A stimuliresponsive and bioactive film based on blended polyvinyl alcohol and cashew gum polysaccharide. Materials Science and Engineering C, 58, 927-934. http://dx.doi.org/10.1016/j. msec.2015.09.064. PMid:26478388.

32. Gomez-Estaca, J., Comunian, T. A., Montero, P., FerroFurtado, R., \& Favaro-Trindade, C. S. (2016). Encapsulation of an astaxanthin-containing lipid extract from shrimp waste by complex coacervation using a novel gelatin-cashew gum complex. Food Hydrocolloids, 61, 155-162. http://dx.doi. org/10.1016/j.foodhyd.2016.05.005.

33. Khodadoust, S., Kouri, N. C., Talebiyanpoor, M. S., Deris, J., \& Pebdani, A. A. (2015). Design of an optically stable $\mathrm{pH}$ sensor based on immobilization of giemsa on triacetylcellulose membrane. Materials Science and Engineering C, 57, 304-308. http://dx.doi.org/10.1016/j.msec.2015.07.056. PMid:26354268.

34. Bayramoğlu, G., \& Arıca, M. Y. (2008). Enzymatic removal of phenol and $p$-chlorophenol in enzyme reactor: horseradish peroxidase immobilized on magnetic beads. Journal of Hazardous Materials, 156(1-3), 148-155. http://dx.doi.org/10.1016/j. jhazmat.2007.12.008. PMid:18207637.

35. Xu, R., Chi, C., Li, F., \& Zhang, F. (2013). Immobilization of horseradish peroxidase on electrospun microfibrous membranes for biodegradation and adsorption of bisphenol. Bioresource Technology, 149, 111-116. http://dx.doi.org/10.1016/j. biortech.2013.09.030. PMid:24096278.

36. Zhang, Y. P., Liu, T. H., Wang, Q., Zhao, J. H., Fang, J., \& Shen, W. G. (2012). Synthesis of novel poly (N,N-diethylacrylamideco-acrylic acid) (P(DEA-co-AA)) microgels as carrier of horseradish peroxidase immobilization for pollution treatment. Macromolecular Research, 20(5), 484-489. http://dx.doi. org/10.1007/s13233-012-0044-z.

37. Vineh, M. B., Saboury, A. A., Poostchi, A. A., Rashid, A. M., \& Pariva, K. (2018). Stability and activity improvement of horseradish peroxidase by covalent immobilization on functionalized reduced graphene oxide and biodegradation of high phenol concentration. Journal of Biological Macromolecules, 106, 1314-1322. http://dx.doi.org/10.1016/j.ijbiomac.2017.08.133. PMid:28851646.

38. Tatsumi, K., Wada, S., \& Ichikawa, H. (1996). Removal of chlorophenols from wastewater by immobilized horseradish peroxidase. Biotechnology and Bioengineering, 51(1), 126-130. http:// dx.doi.org/10.1002/(SICI)1097-0290(19960705)51:1<126::AIDBIT15>3.0.CO;2-O. PMid:18627096.

39. Luz, A. C., Pretti, I. R., Dutra, J. C. V., \& Batitucci, M. C. P. (2012). Evaluation of the cytotoxic and genotoxic potential of Plantago major L. in tests systems in vivo. Revista Brasileira de Plantas Medicinais, 14(4), 635-642. http://dx.doi.org/10.1590/ S1516-05722012000400010.

Received: Jan. 30, 2019 Revised: Sept. 06, 2019 Accepted: Oct. 19, 2019 